\title{
O (DES)SILENCIAMENTO HISTÓRICO EM UM DEFEITO DE COR, DE ANA MARIA GONÇALYGS
}

THE HISTORICAL (DES)SILENCING IN UM DEFEITO DE COR, BY ANA MARIA GONÇALVES

\section{Marinês Andrea Kunz}

Doutora em Linguística e Letras pela Pontifícia Universidade Católica do Rio Grande do Sul (Porto Alegre/Brasil).

Professora Adjunta da Universidade Federal da Paraíba (João Pessoa/Brasil).

E-mail: marinesak@feevale.br

\section{Letícia Moraes Marques}

Mestranda em Processos e Manifestações Culturais pela Universidade Feevale (Novo Hamburgo/Brasil).

E-mail: leticiamoraes@feevale.br

Recebido em: 15 de setembro de 2021

Aprovado em: 9 de novembro de 2021

Sistema de Avaliação: Double Blind Review

RPR | a. 19 | n. 1 | p. 218-233 | jan./abr. 2022

DOI: https://doi.org/10.25112/rpr.v1.2430 


\section{RESUMO}

Este trabalho analisa (des)silenciamento histórico do sujeito negro, especificamente da mulher negra representada pela personagem Kehinde de Um defeito de cor, de Ana Maria Gonçalves, tendo em vista que, ao longo de muitos anos, a narrativa histórica vem negligenciando os relatos históricos do e sobre o centro através da disseminação do discurso patriarcal no ocidente. Os sujeitos contestadores, sejam eles marginalizados ou não, passam a reexaminar os sistemas totalitários que oprimem e omitem outras histórias. Assim sendo, procura-se estudar, por meio de um estudo de cunho bibliográfico, o debate historiográfico e sua relação com a narrativa literária, a fim de analisar a relação da história a respeito do sistema escravocrata no Brasil com a literatura como forma de revisão dessa historiografia, a partir do romance Um defeito de cor, de Ana Maria Gonçalves.

Palavras-chave: Literatura. História. Metaficção. Escravidão.

\section{ABSTRACT}

This work analyzes the historical (de)silence of the black subject, specifically of the black woman represented by the character Kehinde from Um defeito de cor, by Ana Maria Gonçalves, considering that, over many years, the historical narrative has been neglecting the historical accounts of and about the center through the dissemination of patriarchal discourse in the West. The contesting subjects, whether they are marginalized or not, start to re-examine the totalitarian systems that oppress and omit other stories. Therefore, we seek to study, through a bibliographic study, the historiographical debate and its relationship with literary narrative, in order to analyze the relationship of history regarding the slave system in Brazil with literature as a form of review from this historiography, based on the novel Um defeito de cor, by Ana Maria Gonçalves.

Keywords: Literature. History. Metafiction. Slavery. 


\section{INTRODUÇÃO}

Habitantes do silêncio histórico no Brasil desde o "descobrimento" deste, os sujeitos marginalizados da sociedade brasileira, durante um longo período, estiveram imersos nas profundezas do silêncio, emudecidos sem ter a oportunidade de projetar-se social e historicamente para o mundo. Silenciamento que se intensifica de maneira expressiva às mulheres negras na sociedade e suas representações nas narrativas literárias, assim como na produção literária por mulheres negras.

Ao largo de vários anos, a narrativa histórica negligenciou e, de certa forma, continua negligenciando os relatos históricos dos indivíduos à margem, por meio da disseminação do discurso patriarcal no ocidente. No entanto, a partir do século XIX, o imaginário ocidental começa a ser questionado e, no século $X X$, esse questionamento ganha força por meio dos movimentos culturais, artísticos e literários. Abalos que impulsionaram as contestações dos sujeitos, sejam eles marginalizados ou não, e que passaram a reexaminar os sistemas totalitários que oprimem e omitem outras histórias, as que estão fora do centro.

Linda Hutcheon (1991, p. 237) afirma que "o pós-moderno questiona e desmistifica esses sistemas totalizantes que unificam visando ao poder", de modo que o discurso historiográfico predominante passa a sofrer um processo de fragmentação, tendo em vista que abre espaço para a história dos sujeitos à margem, questionando a história oficial, centrada na elite social. Assim sendo, os mecanismos silenciadores da história oficial perdem força, e garante-se, por meio da literatura e outras formas de expressão artística, um novo modo de pensar e considerar a história do sujeito marginalizado pela sociedade. A partir disso, faz-se necessário estudar o discurso descentralizador instaurado pela literatura, pois esta atua como objeto estético, produtor de novas perspectivas históricas e sociais.

Os anos de escravidão no Brasil deixaram marcas devastadoras no território e no povo brasileiro, tanto no âmbito social quanto no cultural e identitário, na formação da sociedade brasileira. Dentre elas, está a visão de que o negro escravizado no Brasil era conivente com sua posição na sociedade, ou seja, que não lutava para libertar-se da dominação do homem branco.

Essa ideia disseminou-se com o passar dos anos e ainda tem crédito na sociedade contemporânea, que segue observando o negro como um sujeito subordinado e que aceita sua condição social. Vistos como uma "peça", os negros não eram reconhecidos em sua humanidade, o que comprova que a história dos escravizados africanos e dos afrodescendentes no Brasil foi e continua sendo negligenciada. Dentre todos os sujeitos sociais, o ponto de vista do negro e, em especial, o da mulher negra são os menos contemplados, social e historicamente. Nessa perspectiva, a história oficial do Brasil e a literatura contribuíram, durante um período significativo, para a consolidação desse discurso, que exclui e rejeita a história do negro como um sujeito capaz de produzir e conduzir sua própria história. 
Nessa perspectiva, ressaltam-se as questões de subalternidade da mulher apontadas por Spivak (2010), que afirma que, se a fala do sujeito subalterno é apagada, a mulher subalterna permanece em um lugar ainda mais marginal, justamente pela questão do gênero. Entretanto, essa marginalização se agrava quando nos debruçamos para as mulheres negras no contexto colonial, em que o sujeito subalterno não tem história e não pode falar, o sujeito subalterno feminino está ainda mais profundamente na obscuridade (SPIVAK, 2010, p. 17).

Em oposição a essa forma de ver a escravidão no Brasil, os movimentos culturais, artísticos e literários surgem como instrumentos de questionamento dos discursos históricos, bem como dos cânones literários. Assim, narrativas literárias metaficcionais, ou seja, que refletem sobre a historiografia, revelam novos pontos de vista e ganham visibilidade e reconhecimento, abrindo espaço para personagens que a história centralizada não contemplou. Modelo exemplar disso é a protagonista Kehinde, de Um defeito de cor, da autoria de Ana Maria Gonçalves, uma escrava africana, que narra sua trajetória de escravidão e busca pela liberdade, atrelada à história do Brasil de uma forma que somente uma alma essencialmente negra e feminina poderia historiar.

Nesse sentido, observa-se que Ana Maria Gonçalves constrói uma literatura que se desloca em direção às ideias de Spivak, ao criar um espaço imagético em que o subalterno pode falar e que pode ser ouvido, como é o caso de Kehinde, que caminha na contramão do estereótipo das personagens negras apresentadas na literatura brasileira, que, geralmente, são infecundas, vistas como objetos de desejo e que fora disso não possuem lugar no espaço ficcional. Kehinde consegue sua liberdade, forma sua própria família e se assume como sujeito centralizador e criador da própria história. Ela possui uma prole, ela prolifera, constrói uma vida e se destaca social e intelectualmente, resgatando a humanidade negra roubada. A voz narrativa de Kehinde se apresenta e labora contra subalternidade, construindo espaços em que os escravizados se articulavam de várias formas, tanto nos movimentos rebeldes quanto nos movimentos silenciosos, mas que sempre almejava a vocalização de uma fala que se queria ser ouvida.

Nascida em África, Kehinde é apanhada ainda menina em sua cidade natal, no Daomé - atual Benin -, e é trazida ao Brasil como escrava. A personagem quebra o silêncio imposto às mulheres negras escravizadas no século XIX, relatando eventos marcados por mortes, estupros, poder, opressão cultural e religiosa, além de pontuar fatos históricos importantes do período, como a Revolução Malê, revolta ordenada por escravizados muçulmanos na Bahia contra a escravidão do homem e a escravidão religiosa (1835), e a Cemiterada (1836), movimento que tinha implicações religiosas e culturais contra a regularização de funerais em cemitérios oficialmente projetados pelas políticas públicas de saneamento da época. 
Kehinde comete o que Conceição Evaristo chama de "insubordinação" ao romper com o estereótipo da mulher negra escravizada de sua época:

[...] quando uma mulher do povo, uma mulher que nasce num espaço que é marcado justamente por relações de subalternidade, quando essa mulher rompe com esse espaço pra se colocar num outro lugar, que não é o lugar que é reservado pra ela [...], eu acho que isso já é um ato de insubordinação (EVARISTO, 2010, p. 8).

A personagem criada por Gonçalves é insubordinada e não admite ser silenciada. Ela assume a roupagem de uma mulher produtora do saber e condutora da sua própria existência. Assim, a protagonista do romance também narra o descrédito de sua sinhá em relação a suas capacidades, visão preconceituosa e que se ramifica na trama social brasileira:

Era um bom desafio e eu gostei de ser desafiada, principalmente porque a sinhá Ana Felipa era quem mais duvidava do meu sucesso. Ela duvidava da parte que sabia, a que eu tinha que pagar a ela, e é claro que nem desconfiava do resto, principalmente em relação ao Banjokô. Ela disse para a Antônia que logo eu pediria para voltar a trabalhar na casa, pois, preguiçosa e lesa do jeito que era, só servia mesmo para trabalhar sob o mando de alguém e para me deitar com homens, que provavelmente devia ser o que eu estava fazendo para conseguir dinheiro (GONÇALVES, 2015, p. 253).

Durante sua busca incessante por liberdade e revolução, Kehinde percorre vários estados do país em busca de um de seus filhos, vendido como escravo pelo pai português. Nessa procura obstinada, a personagem inicia sua investigação na Bahia e acaba passando por Maranhão, São Paulo, Rio de Janeiro e, por fim, em África, evidenciando características culturais próprias de cada local e do período narrado. Diante disso, é importante repensar a história a partir da perspectiva de um sujeito que se enquadra no perfil mais marginalizado no século XIX, que é a mulher negra.

$\mathrm{O}$ (des)silenciamento do sujeito negro a partir da narrativa de Ana Maria Gonçalves configura-se em uma metaficção historiográfica, porque emprega um artifício reformulador de identidade, que consiste na revisão da literatura sobre o debate historiográfico, e sua relação com a narrativa literária, bem como o exame do tempo da história e da ficção no tempo humano refigurado.

\section{A TESSITURA DO TEMPO FICCIONAL E DO HISTÓRICO}

As reflexões a respeito do tempo já foram indagação de estudiosos na Antiguidade. Como exemplo, temos Aristóteles (384 - 322 a.C.) e Santo Agostinho (354 - 430 d.C.), cujas reflexões sobre o tempo serviram de base para estudos de filósofos como Paul Ricoeur (1997), no intento de desvendar os 
mistérios do tempo e a reconfiguração da história humana. Este estudo abordará, assim, a hermenêutica da relação entre tempo e narrativa, delineando os intuitos do romancista e os do historiador por meio da ação de narrar.

Os sujeitos vivem o tempo, e não no tempo, e esse viver o tempo manifesta-se por meio do ato da leitura, que transforma a ação de interpretação em um elemento determinante tanto nas narrativas ficcionais quanto nas narrativas históricas, já que "[...] não somos menos leitores de história do que de romances. Todas as grafias - e, dentre elas, a historiografia - dependem de uma teoria ampliada da leitura" (RICOEUR, 1997, p. 316). Portanto, é imprescindível perceber a função da leitura em um processo recíproco entre a refiguração da vida, do tempo vivido e do tempo narrado.

Com o respaldo de Hayden White (1973), sobre a representância do passado, e de R. Ingarden (1931), a respeito da conjectura da leitura, Ricoeur (1997) elabora a noção de imaginário, além de balizar que, ainda que retalhadas por aporias, ficção e história operam na ação de leitura de refiguração do tempo. A intencionalidade do texto, tanto na produção historiográfica quanto na literária, terá ação efetiva através do ato de leitura, ou seja, o ato de ler se consolida apoiado pela refiguração do tempo, comum à ficção e à história. A conjectura narrativa se concretiza pelo fenômeno do "ver como", denominado referência metafórica em A metáfora viva (2000), que se solidifica apontando o triunfo da noção de figura, na forma do "figurar-se que".

O espaço do imaginário é caracterizado na ficcionalização da história não apenas a partir da função imaginativada narrativa histórica no nível da configuração, mas ao mesmo tempo em relação ao ato do imaginário de enfrentar o passado tal como foi, visto que nas narrativas históricas o imaginário está conectado ao conceito do ter sido, o que, para Ricoeur (1997), não deprecia o caráter realista das análises, mas abriga uma adequada configuração do tempo nos conceitos históricos. A história, segundo o hermeneuta, reinscreve o tempo da narrativa no tempo do universo. $\mathrm{E}$ a união dos dois universos se dá por meio da construção de alguns conectores - calendário, arquivos, rastros, entre outros - que permitem manejar o tempo histórico, possibilitando a aproximação do "tempo cósmico", "tempo vivido" e o "tempo narrado".

Refletindo sobre o entrecruzamento da história e da ficção relacionado ao romance Um defeito de cor, de Ana Maria Gonçalves, observa-se no texto ficcional um jogo lógico entre os conectores mencionados, os quais admitem uma construção ficcional envolvente e consciente do tempo narrativo e do tempo vivido. Isso mostra, acerca da reflexão sobre o imaginário, que

Sempre é possivel estender a lembrança, pela cadeia das memórias ancestrais, remontar o tempo, prolongando pela imaginação esse movimento regressivo; assim como é 
possivel a cada um situar a sua própria temporalidade na sequência das gerações, com o auxílio mais ou menos obrigatório do tempo do calendário (RICOEUR, 1997, p. 319320).

O autor ratifica que a intrincada reconfiguração do tempo tem a capacidade de ser produzida tanto no estudo histórico quanto no estudo literário e afirma que "toda inteligência histórica se enraíza na capacidade que um sujeito tem de se transportar para uma vida psíquica alheia" (RICOEUR, 1997, p. 321). Nesse sentido, reflete sobre o homem como sujeito produtor e conhecedor de suas ações, à medida que ele se desenvolve culturalmente, sempre por meio de um desafio contínuo e truncado de um passado datado (figuração), de um passado reconstruído (refiguração) e de um passado refigurado (reconfiguração).

Ao aludir a analogia do figurar-se como..., Ricoeur (1997) reconhece que a história "imita" em seus escritos os traços estruturais da intriga, legado atribuído à prática literária, entretanto, a função "representativa" da história não se exaure por meio do vínculo dos gêneros literários aos tropos da tradição retórica. No caminho inverso, os empréstimos tomados à história pela literatura viabilizam uma representação imagética significativa a uma mesma obra, em um grande livro de história e um admirável romance. Portanto, permite

[...] ler um livro de história como um romance. Com isso, entramos no pacto de leitura que institui a relação cúmplice entre a voz narrativa e o leitor implicado. Em virtude desse pacto, o leitor baixa a guarda. De bom grado suspende sua desconfiança. Confia. Está pronto para conceder ao historiador o direito exorbitante de conhecer as almas (RICOEUR, 1997, p. 323).

Assim sendo, é possivel reconhecer que a narrativa ficcional, por sua vez, também "imita" a narrativa histórica. É nesse jogo de figuração, refiguração e reconfiguração da vida e do tempo vivido, que o historiador se permite "pintar" uma condição, "restituir" uma teia de sentidos, concedendo a "vivacidade" de uma manifestação interna.

Para o autor, a mediação entre as intrigas, tanto do mundo vivido quanto do mundo narrado, se dá por meio do texto, seja ele histórico ou ficcional. Posto isso, é importante salientar que a ficcionalização da história está longe de invalidar seu propósito de representância. Em razão de que uma das representâncias mencionadas por Ricoeur refere-se aos "[...] acontecimentos que uma comunidade histórica considera marcantes, porque neles vê uma origem ou um redirecionamento" (RICOEUR, 1997, p. 324), tendo em vista que determinados episódios podem corroborar fundamentalmente a formação ou um amparo à consciência da identidade de uma comunidade, bem como sua identidade narrativa e a identidade de 
seus integrantes, conferindo-Ihes sentimentos intensos que devem se manter distantes do historiador enquanto tal.

Já o texto literário "imita" igualmente a narrativa histórica. A essência-narrativa se fundamenta através do "como se passado". A escrita literária é contada em um tempo passado. Pois bem, a narrativa posiciona-se em torno de algo como se fosse um passado verídico, portanto, o tempo passado na narrativa torna-se um "quase passado" dos eventos referidos em uma história ficcional. Desse modo, são esses acontecimentos transformados pela voz narrativa que admitem ponderar como análogas ao autor implicado, isto é, um aspecto fictício do autor real. Consequentemente, configura-se uma aliança na leitura entre o autor e o leitor, atestando "a crença de que os acontecimentos relatados pela voz narrativa pertencem ao passado dessa voz" (RICOEUR, 1997, p. 329).

Logo, pode-se refletir acerca do formato da história e da literatura, uma vez que a história é quase fictícia tanto quanto a ficção é quase histórica.

A história é quase fictícia, tão logo a quase-presença dos acontecimentos colocados "diante dos olhos" do leitor por uma narrativa animada supre, por sua intuitividade, sua vivacidade, o caráter esquivo da passadidade do passado, que os paradoxos da representância ilustram. A narrativa de ficção é quase histórica, na medida em que os acontecimentos irreais que ela relata são fatos passados para a voz narrativa que se dirige ao leitor; é assim que eles se parecem com acontecimentos passados e a ficção se parece com a história (RICOEUR, 1997, p. 329).

0 "quase-passado" da voz narrativa diferencia-se inteiramente do passado histórico, razão por que problematiza o sentido geral da verossimilhança, que, segundo Aristóteles, apresenta-se como provável na acepção do que poderia ter-sido. À vista disso, o autor afirma que "[...] A verdadeira mimese da ação pode ser procurada nas obras de arte menos preocupadas em refletir sua época. $A$ imitação, no sentido vulgar do termo, é aqui o inimigo por excelência da mímese" (RICOEUR, 1997, p. 331). Explica, ainda, que a autenticidade mimética da narrativa se configura pela ruptura da obra com essa "espécie de verossimilhança". Assim sendo, "Essa é a nota 'passadista' que ressoa em toda reivindicação de verossimilhança, fora de qualquer relação de reflexo com o passado histórico" (RICOEUR, 1997, p. 331).

O quase-passado da ficção torna-se assim o detector dos possíveis ocultos no passado efetivo. 0 que 'teria podido acontecer' - o verossímil segundo Aristóteles - recobre ao mesmo tempo as potencialidades do passado 'real' e os possíveis 'irreais' da pura ficção (RICOEUR, 1997, p. 331). 
É essa sobreposição mútua do momento "quase histórico" da ficção que troca de lugar com o momento "quase fictício da história" que configura o entrecruzamento entre a história e a ficção na refiguração do tempo:

Desse entrecruzamento, dessa sobreposição recíproca, dessa troca de lugares, procede o que se convencionou chamar de tempo humano, em que se conjugam a representância do passado pela história e as variações imaginativas da ficção, sobre o pano de fundo das aporias da fenomenologia do tempo (RICOEUR, 1997, p. 332).

Ao versar sobre a "refiguração efetiva do tempo, tornado assim tempo humano, pelo entrecruzamento da história e ficção" (1997, p.315), o autor ratifica que a continuidade discursiva da vida mostra que os fatos históricos não são inertes e que, portanto, "eles são fugidios, escapam, deixam algumas marcas e arranhões, mas nos legam principalmente lacunas e silêncios" (DALCASTAGNĖ, 1996, p. 47). Assim sendo, a literatura e os movimentos pós-modernos contribuem para o (des)silenciamento e o preenchimento das lacunas históricas, buscando romper com o discurso histórico próprio das classes dominantes. Esse discurso hegemônico que perdurou no Brasil por muitos anos não conseguiu, contudo, apagar as histórias construídas pelos marginalizados, mas conseguiu mantê-las submersas. Entretanto, a cultura, a linguagem, a religião e os costumes já estavam consolidados, e o discurso das elites já não pode manter-se sólido.

Nessa perspectiva, "[...] quanto mais explicamos historicamente, mais ficamos indignados; quanto mais ficamos horrorizados mais procuramos compreender" (RICOEUR, 1997, p. 326). Essa possível compreensão acontece através da ficção que vai dar "[...] olhos ao narrador horrorizado. Olhos para ver e para chorar" (RICOEUR, 1997, p. 327), mas não só ao narrador, também ao leitor. Passemos, então, a Kehinde e sua insubordinação.

\section{KEHINDE: A INSUBORDINADA}

Em seu Discurso sobre o colonialismo (1978), Aimé Césaire apresenta uma equação importante acerca do colonialismo, que se define da seguinte forma: colonização = coisificação. Essa equação contribui para a edificação de "[...]sociedades esvaziadas de si próprias, de culturas espezinhadas, de instituições minadas, de terras confiscadas, de religiões assassinadas, de magnificências artísticas aniquiladas, de extraordinárias possibilidades suprimidas" (CÉSARIE, 1978, p. 25). 0 exemplo mais significativo dessa deterioração são as múltiplas culturas e etnias do continente africano atingidas pelo colonialismo europeu. 
A coisificação dos sujeitos escravizados é assinalada por Frantz Fanon em Os condenados da terra (1968), pela violência, artefato que é planejado e balizado na dialética colonial. Fanon refere-se a uma brutalidade que promove a extração da singularidade e da subjetividade do colonizado e que ao mesmo tempo é expelida e nutrida pela conjuntura colonial. Além do mais, observa-se que o choque entre colonizador e colonizado que resultam nessa violência física, epistêmica, simbólica e imagética, jamais teve um viés humanizador e civilizatório, como ressalta Fanon:

violência que presidiu ao arranjo do mundo colonial, que ritmou incansavelmente a destruição das formas sociais indígenas, que arrasou completamente os sistemas de referências da economia, os modos da aparência e do vestuário, será reivindicada e assumida pelo colonizado no momento em que, decidindo ser a história em atos" a massa colonizada se engolfar nas cidades interditas. Fazer explodir o mundo colonial é doravante uma imagem de: ação muito clara, muito compreensivel e que pode ser retomada por cada um dos indivíduos que constituem o povo colonizado. Desmanchar o mundo colonial não significa que depois da abolição das fronteiras se vão abrir vias de passagem entre as duas zonas. Destruir o mundo colonial é, nem mais nem menos, abolir uma zona, enterrá-la profundamente no solo ou expulsá-la do território (FANON, 1968, p. 30).

Essa violência atravessa os escravizados de forma universal, porém, sobretudo, a mulher negra, que, apesar de ser uma exímia colaboradora na construção social, ainda permanece em posição inferior na escala social. Essa posição subterrânea na história não é conferida somente às mulheres do continente africano, mas se estende a todas as mulheres negras escravizadas ao longo do período colonial em todos os países subtraídos pelo regime europeu. A reconstrução e a reposição dos sujeitos marginalizados na sociedade atual estão acontecendo, porém, sua história ainda é narrada de forma muito estereotipada pelo olhar branco. No entanto, narrativas como Um defeito de cor permitem que as histórias desses indivíduos sejam reconstruídas e conhecidas por meio de uma perspectiva histórica negra intermediada pela literatura.

Conceição Evaristo, em seu texto Gênero e Etnia: uma escre(vivência) de dupla face (2005), assevera que,

Colocada a questão da identidade e diferença no interior da linguagem, isto é como atos de criação lingüística, a literatura, espaço privilegiado de produção e reprodução simbólica de sentidos, apresenta um discurso que se prima em proclamar, em instituir uma diferença negativa para a mulher negra. Percebe-se que na literatura brasileira a mulher negra não aparece como musa ou heroína romântica, aliás, representação nem sempre relevante para as mulheres brancas em geral. A representação literária da mulher negra, ainda ancorada nas imagens de seu passado escravo, de corpo-procriação e/ou 
corpo-objeto de prazer do macho senhor, não desenha para ela a imagem de mulhermãe, perfil desenhado para as mulheres brancas em geral (EVARISTO, 2003, p. 2).

O texto literário tramado por Ana Maria Gonçalves rompe com essa imagem acerca da mulher negra ancorada no passado escravocrata brasileiro, visto que sua narrativa tem como personagem principal uma mulher negra que lê, escreve, se posiciona, tem filhos e, apesar de viver em um sistema social opressor, consegue ser independente e livre.

Desde sua chegada ao Brasil, Kehinde se posiciona contra os desmandos dos escravistas, demonstrando que não pretende aceitar a condição que lhe foi imposta brutalmente. Mesmo menina, consegue enxergar as oportunidades que podem levá-la à liberdade. Como escrava de companhia da sinhazinha Maria Clara, ela aproveita as aulas particulares da menina, que é dois anos mais velha que ela, para aprender a ler e escrever. $O$ professor é um muçulmano escravizado chamado Fatumbi, personagem determinante na trajetória de Kehinde. A menina não permite que as oportunidades se esvaiam por entre suas mãos.

As aulas eram dadas na biblioteca, que ficava atrás de uma das portas do imenso corredor, uma que eu nunca tinha visto aberta antes. Fiquei feliz por poder assistir às aulas na qualidade de acompanhante da sinhazinha, e tratei de aproveitar muito bem a oportunidade. Ela nunca estava muito interessada, e o Fatumbi tinha que chamar a atenção dela diversas vezes, como se ele fosse branco e ela fosse preta, motivo que me fez brigar com ele, pois eu achava que ninguém podia falar daquele jeito com a nossa sinhazinha. Mas depois entendi que ele tinha razão, que se ela não quisesse aprender por bem, que fosse por mal. Acho que foi por isso que comecei a admirá-lo, o primeiro preto que vi tratando branco como um igual (GONÇALVES, 2015, p. 92).

O professor percebe o interesse de Kehinde em aprender e decide ajudá-la às escondidas.

Enquanto a sinhazinha Maria Clara copiava as letras e os números que o Fatumbi desenhava no quadro-negro, eu fazia a mesma coisa com o dedo, usando o chão como caderno. Eu também repetia cada letra que ele falava em voz alta, junto com a sinhazinha, sentindo os sons delas se unirem para formar as palavras. Ele logo percebeu o meu interesse e achei que fosse ficar bravo, mas não; até quase sorriu e passou a olhar mais vezes para mim, como se eu fosse aluna da mesma importância que a sinhazinha. Comecei a aprender mais rapidamente que ela, que muitas vezes errava coisas que eu já sabia. As três horas de aula todas as tardes passaram a ser para mim as mais felizes do dia [...] Eu e a sinhazinha passávamos a maior parte do tempo no quarto, ela fingindo estudar e eu estudando de fato, com os livros que não estavam em uso. Um dia antes da chegada do padre Notório, pedi ao Fatumbi que escrevesse para eu copiar o Pai-Nosso e a Ave-Maria, que achei muito mais fáceis de rezar depois de ler e entender. Mostrei para 
a Esméria e ela disse que nunca poderia imaginar que ali, naquele monte de tracinhos que não diziam nada, pelo menos para ela, estavam orações tão bonitas. Eram mesmo orações bonitas, que mais tarde também aprendi em iorubá, eve-fon e, muitos anos depois, em inglês e em francês (GONÇALVES, 2015, p. 92-93).

O encontro com o conhecimento, com a leitura e com a escrita permite que Kehinde se construa diferentemente de outros escravizados a sua volta. A libertação da sua alma africana se manifesta por meio da leitura e dos livros, ou seja, por meio da literatura e do conhecimento. Comete, pois, um ato de liberdade e insubordinação ao aprender a ler e escrever.

Observa-se também que o romance rompe com outro ciclo, ou seja, a série de histórias criadas e contadas por mulheres negras para adormecer a casa-grande, o que vai ao encontro da fala de Evaristo, em entrevista à TV Brasil:

Quando estou escrevendo e quando outras mulheres negras estão escrevendo, me vem à memória a função que as mulheres africanas - dentro das casas-grandes, escravizadas - tinham de contar histórias para adormecer a casa-grande. Eram histórias para adormecer. Nossos textos tentam borrar essa imagem. Nós não escrevemos para adormecer os da casa-grande, pelo contrário, é para acordá-los dos seus sonos injustos.

Portanto, a narrativa combate outro estereótipo histórico. Ao produzir um texto que mostra a força da voz de uma mulher negra que conta sua história, Gonçalves faz barulho para acordar aqueles que dormem tranquilos à custa de muita desigualdade e sofrimento.

De nome Kehinde e sobrenome Insubordinada, a narradora vinga a sua coletividade por meio dos dois maiores atos de resistência e liberdade: a leitura e a escrita. Ao chegar ao Brasil, demonstra de imediato que não vai se render ao regime instaurado. Ela nasce rodeada de palavras, sua cultura é oral, no entanto, no novo território, sua oralidade e suas palavras são insuficientes para que ela se mantenha em pé e continue seguindo. Tomar posse da escrita e do saber ler é um ato extremamente desobediente, independente, ou seja, insubordinado. Essa condição independente permite que a narradora cumpra dois objetivos importantes:

Ser a voz narrativa, e não a voz narrada, ou seja, ser sujeito da sua história e descrever a história dessa época sob a perspectiva de alguém que viveu esse período como vítima da sociedade escravista, uma escrava, e não como um membro da sociedade ocidental branca que a criou (VASCONCELOS, 2015, p. 233).

Kehinde caminha, pois, na oposição do estereótipo das mulheres negras da literatura brasileira, na medida em que romances conceituados da nossa literatura objetificam e sensualizam o corpo da mulher 
negra (Rita Baiana e Gabriela), concebem-na como infecunda (Rita Baiana e Gabriela) e animalesca (Bertoleza). Amparada por José Maurício Gomes Almeida, Evaristo ratifica essa ideia:

O romance abolicionista, A Escrava Isaura (1875), de Bernardo Guimarães, não se trata de uma heroína negra, como também observa Almeida (ibid. 96-7). Na narrativa a senhora elogia a tez clara da escrava e mais parece felicitar a moça por ter tão pouco 'sangue africano', dizendo-Ihe: 'És formosa, e tens uma cor linda, que ninguém dirá que gira em tuas veias uma só gota de sangue africano'. (EVARISTO, 2003, p. 3).

Observa-se, assim, que tanto a historiografia quanto a literatura, involuntária ou voluntariamente, contribuíram com o apagamento dos sujeitos marginais, em específico a mulher negra. Na via oposta, a narrativa ficcional de Gonçalves apresenta uma narradora negra que se opõe aos estereótipos. 0 protagonismo ignorado, construído pelo sistema escravocrata, é contrariado por meio da feminista Kehinde, dado que,

[...] a personagem não se deixa dominar por homens, depois de liberta e, mesmo quando apaixonada, não abandona seus objetivos ou abre mão da independência financeira, por exemplo. Consideramos importante o fato da autora ter escolhido para sua personagem uma família formada por mãe e avó, mulheres fortes e independentes, sem nenhum homem que Ihes questionasse as decisões. Esta característica é também importante na forma como vivencia suas experiências maternais. Em cada uma das vezes em que engravida, Kehinde tem um relacionamento bem diverso com cada um dos pais dos seus filhos: com o primeiro vivencia a violência de um estupro, com o segundo um relacionamento amoroso e com o terceiro um casamento e uma parceria de negócios; no entanto, em todos os casos, tem os filhos como prioridade sobre os pais deles; sua família se constitui sobretudo dos filhos e amigos mais próximos, sobretudo as mulheres (VASCONCELOS, 2015, p. 262).

Contudo, o texto não se estende somente às mulheres negras, uma vez que busca recompor a imagem de outras vozes dessa coletividade negra por meio dos movimentos organizacionais compostos pela representação das Cooperativas e da Rebelião Malê. Mesmo assim, muitas histórias dessa coletividade negra sem dúvida permanecem nos escombros da memória, visto que, como afirma Maria Nova, personagem de Becos da Memória de Conceição Evaristo,

[...] sobre escravos e libertação, ela teria para contar muitas vidas. Que tomaria a aula toda e não sabia se era isso que a professora queria. Tinha para contar sobre uma senzala que, hoje, seus moradores não estavam libertos, pois não tinham nenhuma condição de vida (EVARISTO, 2017, p. 150). 
No entanto, ainda que leve muitas vidas para se contar não tudo, mas uma parcela da história desses agrupamentos, é imprescindivel que a invocação do passado seja realizada, seja por novas investigações historiográficas seja por escritos ficcionais. Essa necessidade investigativa, segundo Edward Said, em Cultura e imperialismo (2011), se faz pertinente e necessária, visto que,

A invocação do passado constitui uma das estratégias mais comuns nas interpretações do presente. 0 que inspira tais apelos não é apenas a divergência quanto ao que ocorreu no passado e o que teria sido esse passado, mas também a incerteza se o passado é de fato passado, morto e enterrado, ou se persiste, mesmo que talvez sob outras formas. Esse problema alimenta discussões de toda espécie - acerca de influências, responsabilidades e julgamentos, sobre realidades presentes e prioridades futuras. (SAID, 2011, p. 34).

O constructo fictício de Um defeito de correvela a importância do debate sobre as informações históricas registradas no plano ficcional, pontuando temas de convergência entre os fatos que balizaram os séculos de escravidão, em específico o século XIX neste estudo. A travessia do Oceano Atlântico de África até o Brasil é um dos pontos problematizados até pouco tempo pela historiografia através do lugar de fala do homem branco ocidental. Ao dar voz a Kehinde, Ana Maria Gonçalves articula, por meio da literatura, um lugar de fala a um sujeito amordaçado pela sociedade e, consequentemente, pela história oficial: o negro, visto que ele não possui lugar de fala deixa de existir para o outro. Com isso, pode-se observar que a narradora-personagem impõe a existência de uma história negra e de sujeitos negros, "[...] uma vez que falar é existir absolutamente para o outro" (FANON, 2008, p. 33).

Para Bakhtin (2006), a palavra é a arena onde se confrontam os valores sociais contraditórios, e é exatamente isso que o romance se propõe a fazer. O lugar de fala de Kehinde, como mulher, negra, africana e escravizada, em um primeiro momento, e depois como liberta, lhe permite a produção de um discurso questionador que desnuda os mecanismos contraditórios do sistema escravocrata do Brasil, assim como de África. Esse direito de fala questionadora possibilita a Kehinde articular as ações, o tempo e os espaços vividos por ela e pelos personagens que a cercam, garantindo sentimentos e vida ao texto.

Os relatos ficcionais ajudam os indivíduos a responder às inquietações diante da realidade por apresentarem, de forma inteligivel, situações humanas que a experiência cotidiana expõe de modo precário e confuso. Portanto, é por meio do universo ficcional que Gonçalves desloca o leitor e desafia-o a pensar e rever o presente à luz desse redimensionamento do passado, buscando uma possível compreensão ou talvez um entendimento de que, a bem da verdade, "o tempero do oceano atlântico foi feito por lágrima de preto" (EMICIDA, 2015). 


\section{CONSIDERAÇÕES FINAIS}

A história do Brasil é abalizada pela escravidão, e a literatura constitui um meio que possibilita a ficcionalização da história com o intuito da representância, uma vez que esse episódio está ligado ao horror, o qual não deve e não pode ser esquecido, a fim de que não se repita. Nesse sentido, a ficção atua como um agente significativo na preservação da memória do horror e, neste caso, a partir do ponto de vista daquele que foi escravizado, mostrando, dessa forma, as lutas pelo direito à vida e à liberdade.

A voz narrativa do texto ficcional abre uma brecha em meio aos discursos hegemônicos, revelando as lutas havidas para romper com os grilhões da escravidão, enfoque necessário no Brasil, tendo em vista que muitos ainda acreditam que não houve resistência nem luta por parte dos escravizados. Porém, essa ação - experiência viva do discurso histórico e literário -, que se põe a serviço do que deve ser inesquecivel, só acontece de fato por meio da justaposição entre o tempo "quase histórico da ficção" e o tempo "quase fictício da história", tempos que se correlacionam no texto de Um defeito de cor.

Pela narrativa de sua vida, Kehinde, a protagonista, empresta o olhar horrorizado ao leitor, no intuito de convidá-lo a mirar a história brasileira da margem para o centro, des-centrando discursos e portanto, des-silenciando vozes, que, por muito tempo, apesar de seus esforços, não conseguiam romper as malhas discursivas mais poderosas. Reflete, portanto, sobre a permanência, na contemporaneidade, de resquícios do passado escravocrata e violento nas malhas sociais.

As reminiscências do passado histórico e ancestral dos sujeitos negros e dos afro-brasileiros são, assim, reconstruídas por meio do recurso metaficcional, que vai passar a limpo alguns episódios da história do Brasil em seu contexto escravocrata, problematizando-o mediante a ficcionalização do vivido, o que constitui um espaço de reflexão para questionar as iminências do presente. Rememorando, reelaborando e reescrevendo, a literatura cumpre seu papel como arte, incidindo sobre o presente, em que ainda ecoam dores pretéritas.

\section{REFERÊNCIAS}

CÉSAIRE, Aimé. Discurso sobre o colonialismo. Lisboa: Livraria Sá da Costa, 1978.

DALCASTGNĖ, Regina. 0 espaço da dor. 0 regime de 64 no romance brasileiro. Brasília: Universidade de Brasília, 1996.

DALCASTGNĖ, Regina (Org.). Ver e imaginar o outro. São Paulo: Horizonte, 2008. 
EMICIDA; NAVE. Boa Esperança. Álbum: sobre Crianças, Quadris, Pesadelos e Lições de Casa.

Compositores: Leandro Oliveira, Letra de Boa Esperança, 2015. Disponível em: HTTPS://www.youtube. com/watch?v=s96Xp0EmfDw. Acesso em: 02 de mai. 2018.

ENTREVISTA À TV BRASIL. Entrevistada: Conceição Evaristo. Entrevistadora: Bárbara Araújo Machado. Rio de Janeiro, 30 set. 2010. Disponivel em: http://tvbrasil.ebc.com.br/estacao-plural/2017/06/naoescrevemos-para-adormecer-os-da-casa-grande-pelo-contrario-diz-conceicao. Acesso em: 5 Jun. 2018.

EVARISTO, Conceição. Gênero e etnia: uma escre(vivência) de dupla face. In: MOREIRA, Nadilza Martins de Barros; SCHNEIDER, Liane (Org.). Mulheres no mundo: etnia, marginalidade e diáspora. João Pessoa: Ideia; Editora Universitária UFPB, 2005.

EVARISTO, Conceição. Becos da Memória. Rio de Janeiro: Pallas, 2017.

FANON, Frantz. Os Condenados da Terra. Trad. de José Laurênio de Melo. Rio de Janeiro: Civilização Brasileira, 1968.

FANON, Frantz. Pele negra, máscaras brancas. Salvador: EDUFBA, 2008.

GONÇALVES, Ana Maria. Um defeito de cor. Rio de Janeiro: Record, 2015.

HUTCHEON, Linda. Poética do Pós-modernismo: história, teoria, ficção. Rio de Janeiro: Imago, 1991.

RICOEUR, Paul. Tempo e narrativa. Tomo III. Campinas, São Paulo: Papirus, 1997.

SAID, Edward. Cultura e imperialismo. São Paulo: Companhia das Letras, 2011.

SPIVAK, Gayatri Chakravorty. Pode o subalterno falar? 1. ed. Trad. Sandra Regina Goulart Almeida; Marcos Pereira Feitosa; André Pereira. Belo Horizonte: Editora da UFMG, 2010.

VASCONCELOS, Vania Maria Ferreira de. No colo das iabás: raça e gênero em escritoras afro-brasileiras. Fortaleza: Edições Demócrito Rocha, 2015. 